\title{
Kahramanmaraş Sütçü İmam Üniversitesi Sağlık Uygulama ve Araştırma Hastanesi'nde Kan Kültürlerinden İzole Edilen Mikroorganizmalar ve Antibiyotik Duyarlılıkları
}

\author{
Microorganism Isolated from Blood Culture and Their Antimicrobial \\ Susceptibilities Obtained at Kahramanmaraş Sütcü Imam University \\ Health Practice and Research Hospital
}

\section{Burak Küçük, Gökhan Arıcan, Damla Gülderen, Hacer Uğurlu,} Kezban Tülay Yalçınkaya, Murat Aral

Kahramanmaraş Sütçü İmam Üniversitesi Sağlık Uygulama ve Araștırma Hastanesi Tibbi Mikrobiyoloji Laboratuvarı

\section{Yazışma Adresi / Correspondence:}

\section{Burak Küçük}

Kahramanmaraş Sütçü İmam Üniversitesi Sağlık Uygulama ve Araştırma Hastanesi Tibbi Mikrobiyoloji Laboratuvarı Avşar Mah. Batı Çevreyolu Blv. No:251/A 46040 Onikişubat/Kahramanmaraș

T: +905353032808 E-mail: : dr.burakkucuk@gmail.com

Geliş Tarihi / Received : 22.07.2019 Kabul Tarihi / Accepted : 02.09.2019

Orcid :

Burak Küçük: https://orcid.org/0000-0001-5596-3347

Gökhan Arıcan: https://orcid.org/0000-0002-2002-1904

Damla Gülderen: https://orcid.org/0000-0002-6645-9266

Hacer Uğurlu: https://orcid.org/0000-0001-6126-5502

Kezban Tülay Yalçınkaya: https://orcid.org/0000-0002-6324-4585

Murat Aral: https://orcid.org/0000-0002-3576-4380

Öz

Amaç Kan dolaşımı enfeksiyonları, mortalite ve morbiditenin önde gelen nedenlerinden biridir. Calıșmamızın amacı kan kültürlerinde en sık belirlenen enfeksiyon etkenlerini ve antibiyotik duyarlılıklarını saptamaktır. ( Sakarya Tıp Dergisi 2019, 9(3):485-491)

Gereç ve 1 Ocak 2018 - 31Aralık 2018 tarihleri arasında çalıșlan 3719 izolat çalıșmaya dahil edilmiștir. Kan kültürü örnekleri BACT/ALERT 3D otomatize sistemi ile inkübe

1 Ocak 2018 - 31Aralık 2018 tarihleri arasında çalıșllan 3719 izolat çalışmaya dahil edilmiştir. Kan kültürü örnekleri BACT
edilmiștir. Üreyen mikroorganizmaların identifikasyonu ve antibiyotik duyarlılıkları Phoenix otomatize sistem ile yapılmıștı

Bulgular Çalışmaya dahil edilen 3719 kan kültürü örneğinin 2822'sinde (\%75.8) Gram pozitif bakterilerin, 584’ünde (\%16.7) Gram negatif bakterilerin, 180’inde (\%4.8) mayaların ürediği görülmüstür. En sık izole edilen Gram negatif bakteriler Escherichia coli 227 (\%36.37), Klebsiella pneumoniae 126 (\%20.19) olarak bulunmuștur. Gram pozitif bakterilerin 2245'inin koagülaz negatif Staphylococcus türleri, 251'inin (\%8.8) Enterococcus spp., 194'ünün (\%6.87) Staphylococcus aureus olduğu saptanmıștır.

Gram negatif bakterilere en etkili antibiyotikler karbapenemler, aminoglikozidler ve tigesiklin olarak bulunmuştur. Tüm Acinetobacter izolatları karbapenemlere dirençli bulunmuștur. Staphylococcus aureus izolatlarında vankomisin direnci saptanmazken metisilin direnci \% 55 , koagülaz negatif Staphylococcus izolatlarında metisilin direnci \%84 olarak bulunmuștur. Enterococcus spp. izolatlarında vankomisin direnci \%9.7 olarak bulunmuștur

Sonuç olarak bakterilerin direnç oranlarının bu denli yüksek olması enfeksiyon kontrol önlemlerinin artırılması gerektiğini düșündürmektedir

Objective Blood stream infections remain a major cause of morbidity and mortality. The aim of this study is to determine the types of microorganisms and antibiotic susceptibility isolated from blood cultures. (Sakarya Med J 2019, 9(3):485-491). coli 227 (36.3\%), Klebsiella pneumoniae 126 (20.1\%). The most frequent Gram positive bacteria were 2245 (79.5\%) coagulase negative Staphylococcus, 251 (8.8\%) Enterococcus spp., 194 (6.87\%) Staphylococcus aureus.

Carbapenems, aminoglycosides and tigecycline were most effective antibiotics against all Gram negatives. All Acinetobacter isolates were resistant to carbapenems. No resistance to vancomycin was detected Staphylococcus aureus. Methicilin resistance was 55\% to Staphylococcus aureus, $84 \%$ to coagulase negative Staphylococcus. Vancomycin resistance was $9.7 \%$ to Enterococcus spp.. 


\section{GIIRIŞ}

Kan dolaşımı enfeksiyonları, en sık karşılaşılan invazif enfeksiyonlardan biri olup mortalite ve morbiditenin önde gelen nedenlerinden biridir. ${ }^{1-4}$ Kan dolaşımı enfeksiyonlarına neden olan etkenin erken tanısı ve uygun antimikrobiyal tedavisi mortaliteyi anlamlı oranda azaltmaktadır. ${ }^{1-4}$ Kuzey Amerika ve Avrupa'yı kapsayan bir çalışmada kan dolaşımı enfeksiyonunun ölümün önde gelen 7 nedeninden biri olduğu belirlenmiştir. ${ }^{2}$ Geçmişten günümüze önemli bir sağlık sorunu olan kan dolaşımı enfeksiyonlarında en kısa sürede mikroorganizmanın tanımlanması ve uygun tedavinin planlanması gerekmektedir.

Kan dolaşımı enfeksiyonlarına çeşitli mikroorganizmalar neden olabilmektedir. En sık karşılaşılan enfeksiyon etkenlerine bakıldığı zaman gram pozitif koklar (özellikle Staphylococcus ve Enterococcus spp.), gram negatif basiller (özellikle Pseudomonas aeruginosa, Escherichia coli, Acinetobacter ve Klebsiella türleri) karşımıza çıkmaktadir. $^{5-7}$

Çalışmamızın amacı kan kültürlerinde en sık belirlenen enfeksiyon etkenlerini ve antibiyotik duyarlılıklarını saptamaktır.

\section{GEREÇ YÖNTEM}

Çalışmamızda 1 Ocak 2018 - 31Aralık 2018 tarihleri arasında Kahramanmaraş Sütçü İmam Üniversitesi Sağlık Uygulama ve Araştırma Hastanesi Tibbi Mikrobiyoloji Laboratuvarı'na gelen 11579 kan kültürü retrospektif olarak değerlendirilmiştir. Hastalardan alınan kan örnekleri kan kültür şişelerine (yetişkinler için Bactec plus aerobic/Bactec plus anaerobic, çocuklar için Bactec peds plus/ kan kültür şişeleri) konulduktan sonra şişeler BACT/ALERT 3D sistemine yüklenmiştir.

Kan kültürü örnekleri BACT/ALERT 3D (BioMérieux, Marcy I'Etoile, Fransa) otomatize sistemi ile 5 gün inkübe edilmiştir. Brucella enfeksiyonu şüphesi olan örneklerin inkübasyonu 10 güne uzatılmıştır. Bu süre sonunda pozitif sinyal veren örneklerin \%5 koyun kanlı agar, eozin metilen blue agar, çukulata agar besiyerlerine ekimleri yapılmıştır. Ekimleri yapılan koyun kanlı agar ve eozin metilen blue agar besiyerleri $24-48$ saat $37^{\circ} \mathrm{C}$ de, çukulata agar ise 24 48 saat \%5 CO2'li koşullarda inkübe edilmiştir. Bu süre sonunda üreyen mikroorganizmalar koloni morfolojisi incelenerek, Gram boyama ve biyokimyasal özelliklerine göre identifikasyon ve antibiyotik duyarlılık çalışmaları konvansiyonel yöntemler ve Phoenix otomatize sistem (Becton Dickinson, Sparks, Maryland, ABD) ile yapılmış olup sonuçlar The European Committee on Antimicrobial Susceptibility Testing (EUCAST) kriterlerine göre değerlendirilmiştir. Beş gün süreyle inkübe edilen ve cihazın bu süre içerisinde pozitif sinyal vermediği şişeler negatif olarak değerlendirilmiştir.

Cilt florasında bulunan bir veya birden fazla organizmanın hastanın birden fazla kan kültürü setinden sadece birinde (örneğin; bir setin bir veya daha fazla şişesinde, iki setin birinde, üç setin birinde) üremesi ve hastanın bu organizma ile enfeksiyonuna dair klinik veya mikrobiyolojik kanıtın bulunmaması kontaminasyon olarak kabul edilmiştir. $\mathrm{Bu}$ doğrultuda koagülaz negatif Staphylococcus (KNS) türleri, Propionibacterium türleri, Bacillus anthracis dışındaki Bacillus türleri, Corynebacterium türleri, Aerococcus türleri ve Micrococcus türleri kontaminasyon olarak değerlendirilmiştir.

Çalışmamız kesitsel tipte tanımlayıcı araştırma örneği olup, Kahramanmaraş Sütçü İmam Üniversitesi Tıp Fakültesi Klinik Araştırmalar Etik Kurulu tarafından 30.04.2019 tarihinde 125 protokol numarası ile onaylanmıştır. Çalışmamızda herhangi bir istatistiksel yöntem kullanılmamış olup veriler yüzde olarak hesaplanmıştır.

\section{BULGULAR}

Çalıșmamıza 1 Ocak 2018 ile 31 Aralık 2018 arasında Kahramanmaraş Sütçü İmam Üniversitesi Tip Fakültesi Hastanesi’nde yapılan 11579 kan kültürü örneği dahil edilmiştir. Bu kültürlerin 870 tanesi (\%8.38) kontaminasyon olarak 
değerlendirilmiştir.

Gönderilen 11579 kan kültürünün 3373'ünde (\%29.13) üreme olurken, 346 örnekte polimikrobiyal üreme tespit edilmiştir. Toplam 3719 tür mikroorganizma saptanmıştır. İzole edilen 3719 mikroorganizmanın 2822'sinin (\%75.88) Gram pozitif bakteriler, 584'ünün (\%16.77) Gram negatif bakteriler, 91'inin (\%2.44) Candida albicans türü mayalar, 89'unun (\%2.39) Non-albicans Candida spp. türü mayalar olduğu belirlenmiştir. Gram negatif bakterilerin 227'si (\%36.37) Escherichia coli, 126’s1 (\%20.19) Klebsiella pneumoniae, 83'ü (\%13.3) Acinetobacter baumannii, 73’ü (\%11.69) Pseudomonas aeruginosa olarak tanımlanmıştır. Gram pozitif bakterilerden en sık izole edilenlerin; 2245’inin (\%79.55) KNS türleri, 194'ünün (\%6.87) S.aureus olduğu belirlenmiştir. Metisilin dirençli KNS oranı $\% 84$, metisilin dirençli S.aureus oranı ise \%55 olarak belirlenmiştir. Mayalar içinde izole edilen en sık türün Candida albicans (\%2.44) olduğu belirlenmiştir. Üreyen tüm mikroorganizmaların dağılımı Tablo 1'de verilmiştir. Üreyen mikroorganizma örneklerinin en sık dahili birimlerden geldiği görülmüş olup izolatların kliniklere göre dağılımı Tablo 2'de verilmiştir. Gram negatif bakterilere en etkili antibiyotikler karbapenemler, aminoglikozidler ve tigesiklin olarak bulunurken, tüm A.baumannii izolatlarının karbapenemlere dirençli olduğu görülmüştür. Acinetobacter suşlarında kolistin direnci ise saptanmamıştır. Vankomisin direnci S.aureus ve KNS türlerinde saptanmazken, Enterecoccus spp'de \%9.79 olarak bulunmuştur. Tablo 3'te üreyen nonfermantatif bakterilerin, Tablo 4'te en sık üreyen gram pozitif bakterilerin, Tablo 5 'te en sik üreyen gram negatif bakterilerin, Tablo 6'da üreyen mayaların antibiyotik/antifungal dirençleri sayı ve yüzde şeklinde verilmiştir.

\begin{tabular}{|l|c|}
\hline Tablo 1. Kan kültüründe üreyen bakterilerin dă̆llımı [ $\mathbf{n}(\%)]$ \\
\hline & $\mathrm{n}(\%)$ \\
\hline Koagülaz Negatif Staphylococcus & $2245(60.3)$ \\
\hline Enterococcus spp. & $251(6.74)$ \\
\hline Escherichia coli & $227(6.1)$ \\
\hline Staphylococcus aureus & $194(5.21)$ \\
\hline Klebsiella pneumoniae & $126(3.38)$ \\
\hline Candida albicans & $91(2.44)$ \\
\hline Non-albicans Candida spp. & $89(2.39)$ \\
\hline Acinetobacter baumannii & $83(2.23)$ \\
\hline Pseudomonas aeruginosa & $73(1.96)$ \\
\hline Corynebacterium spp. & $69(1.85)$ \\
\hline Streptococcus spp. & $45(1.21)$ \\
\hline Enterobacter spp. & $24(0.64)$ \\
\hline Serratia marcescens & $19(0.51)$ \\
\hline Burkholderia cepacia & $17(0.45)$ \\
\hline Klebsiella spp. & $16(0.43)$ \\
\hline Proteus mirabilis & $11(0.29)$ \\
\hline Streptococcus pneumoniae & $11(0.29)$ \\
\hline Stenotrophomonas maltophilia & $9(0.24)$ \\
\hline Salmonella spp. & $9(0.24)$ \\
\hline Citrobacter spp. & $8(0.21)$ \\
\hline Streptococcus agalactiae & $5(0.13)$ \\
\hline Streptococcus pyogenes & $2(0.05)$ \\
\hline Brucella spp. & $2(0.05)$ \\
\hline Diğer & $93(2.5)$ \\
\hline Toplam & $3719(100)$ \\
\hline
\end{tabular}

\begin{tabular}{|l|c|}
\hline \multicolumn{2}{|l|}{ Tablo2. Üreyen bakterilerin kliniklere göre dağılımı [ $\mathbf{n}(\%)$ ] } \\
\hline Cerrahi Birimler & $\mathrm{n}(\%)$ \\
\hline Dahili Birimler & $395(10.64)$ \\
\hline Yoğun Bakım & $2292(61.68)$ \\
\hline Toplam & $1032(27.77)$ \\
\hline
\end{tabular}


Sakarya Tip Dergisi 2019;9(3):485-491

KÜÇÜK ve Ark. Kan Kültürü Mikroorganizmaları ve Antibiyotik Duyarllııları

\begin{tabular}{|l|c|c|c|}
\hline Tablo 3. En sık izole edilen nonfermentatif bakterilerde belirlenen antibiyotik direnç oranları \\
\hline & Pseudomonas aeruginosa $\mathrm{n}(\%)$ & Acinetobacter baumannii $\mathrm{n}(\%)$ & Burkholderia cepacia $\mathrm{n}(\%)$ \\
\hline Amikasin & $11 / 73(15.07)$ & $72 / 82(87.8)$ & $1 / 1(100)$ \\
\hline Colistin & $3 / 72(4.17)$ & $0 / 83(0)$ & $1 / 1(100)$ \\
\hline Gentamisin & $22 / 73(30.14)$ & $80 / 82(97.5)$ & $1 / 1(100)$ \\
\hline İmipenem & $27 / 72(37.5)$ & $83 / 83(100)$ & $3 / 3(100)$ \\
\hline Meropenem & $22 / 71(30.9)$ & $83 / 83(100)$ & - \\
\hline Sefepim & $26 / 72(36.1)$ & $3 / 3(100)$ & $1 / 1(100)$ \\
\hline Seftazidim & $31 / 73(42.4)$ & $3 / 3(100)$ & $1 / 1(100)$ \\
\hline Siprofloksasin & $16 / 62(25.8)$ & $73 / 75(97.3)$ & $1 / 1(100)$ \\
\hline Piperasilin/tazobaktam & $24 / 72(33.3)$ & $4 / 4(100)$ & $0 / 14(0)$ \\
\hline Trimetoprim/sulfametoksazol & $1 / 1(100)$ & $59 / 83(71.08)$ & \\
\hline${ }^{*}$ Dirençli izolat sayısı / Çalıșlan izolat sayısı & & \\
\hline
\end{tabular}

\begin{tabular}{|l|c|c|c|}
\hline Tablo 4. En sık izole edilen gram pozitif bakteriler ve antibiyotik direnconları [ $\mathbf{n}(\%)]^{*}$ \\
\hline & KNS $^{* *} \mathrm{n}(\%)$ & Staphylococcus aureus $\mathrm{n}(\%)$ & Enterococcus spp. n (\%) \\
\hline Ampisilin & $1791 / 1824(98.10)$ & $87 / 92(94.57)$ & $108 / 239(45.18)$ \\
\hline Clindamisin & $1226 / 2092(58.60)$ & $60 / 185(32.43)$ & $12 / 13(92.3)$ \\
\hline Daptomisin & $73 / 2089(3.49)$ & $1 / 184(0,54)$ & $2 / 2(100)$ \\
\hline Eritromisin & $1659 / 2131(77.85)$ & $66 / 188(35.11)$ & $8 / 4(100)$ \\
\hline Fosfomycin & $549 / 2111(26.00)$ & $10 / 188(5.32)$ & $69 / 234(100)$ \\
\hline Gentamisin & $1002 / 2134(46.95)$ & $21 / 185(11.35)$ & $0 / 148(0)$ \\
\hline Linezolid & $116 / 2116(5.48)$ & $3 / 188(1.60)$ & $5 / 5(100)$ \\
\hline Oxaxilin & $1779 / 2105(84.51)$ & $102 / 185(55.14)$ & $234 / 234(100)$ \\
\hline Siprofloksasin & $1291 / 2094(61.65)$ & $15 / 185(8.11)$ & $24 / 245(9.79)$ \\
\hline Trimetoprim/sulfametoksazol & $18 / 1436(1.25)$ & $0 / 172(0)$ & $0 / 189(0)$ \\
\hline Vankomisin & $0 / 1171(0)$ & & \\
\hline${ }^{*}$ Dirençli izolat sayıs1 / Çalıșlan izolat sayıs1 ${ }^{*}$ Koagülaz negatif Staphylococcus & \\
\hline
\end{tabular}

Tablo 5. En sık izole edilen Gram negatif bakteriler ve antibiyotik direnç oranları [ $\mathbf{n}(\%)]^{*}$

\begin{tabular}{|l|c|c|c|c|}
\hline & $\begin{array}{c}\text { Escherichia coli } \\
\mathrm{n}(\%)\end{array}$ & $\begin{array}{c}\text { Klebsiella pneumoniae } \\
\mathrm{n}(\%)\end{array}$ & $\begin{array}{c}\text { Proteus mirabilis } \\
\mathrm{n}(\%)\end{array}$ & $\begin{array}{c}\text { Salmonella spp. } \\
\mathrm{n}(\%)\end{array}$ \\
\hline Amikasin & $2 / 227(0.88)$ & $25 / 123(20.33)$ & $0 / 11(0)$ & $9 / 9(100)$ \\
\hline Amoxicillin-Clavulanate & $150 / 217(69.1)$ & $89 / 116(76.72)$ & $6 / 11(54.55)$ & $0 / 9(0)$ \\
\hline Ceftriaxone & $160 / 221(72.4)$ & $98 / 124(79.03)$ & $5 / 11(45.45)$ & $0 / 9(0)$ \\
\hline Ertapenem & $39 / 220(17.3)$ & $53 / 124(42.74)$ & $1 / 11(9.09)$ & $0 / 9(0)$ \\
\hline Gentamisin & $73 / 224(32.59)$ & $51 / 124(41.13)$ & $4 / 11(36.36)$ & $9 / 9(100)$ \\
\hline Meropenem & $16 / 222(7.21)$ & $27 / 123(21.95)$ & $0 / 11(0.00)$ & $0 / 9(0)$ \\
\hline Piperasilin/tazobaktam & $65 / 225(28.89)$ & $64 / 124(51.61)$ & $0 / 11(0.00)$ & $0 / 9(0)$ \\
\hline Sefepime & $140 / 224(62.5)$ & $96 / 124(77.42)$ & $3 / 11(27.27)$ & $0 / 9(0)$ \\
\hline Sefuroksim & $161 / 215(74.8)$ & $99 / 123(80.49)$ & $7 / 11(63.64)$ & - \\
\hline Siprofloksasin & $142 / 221(64.25)$ & $55 / 113(48.67)$ & $5 / 11(45.45)$ & $0 / 6(0)$ \\
\hline Tigecycline & $0 / 217(0)$ & $11 / 124(8.87)$ & $11 / 11(100)$ & $0 / 9(0)$ \\
\hline Trimetoprim/sulfametoksazol & $116 / 224(51.79)$ & $79 / 124(63.71)$ & $7 / 11(63.64)$ & $0 / 9(0)$ \\
\hline${ }^{*}$ Dirençli izolat sayıs1 / Çalışlan izolat sayıs1 & & & \\
\hline
\end{tabular}




\begin{tabular}{|l|c|c|}
\hline \multicolumn{3}{|c|}{$\left.\begin{array}{c}\text { Tablo 6. Kan kültüründen izole edilen mayalar ve belirlenen } \\
\text { antibiyotik/antifungal direnç oranları [ } \mathbf{n}(\%)\end{array}\right]^{*}$} \\
\hline & $\begin{array}{c}\text { Candida albicans } \\
\mathrm{n}(\%)\end{array}$ & $\begin{array}{c}\text { Non-albicans } \\
\text { Candida spp. } \\
\mathrm{n}(\%)\end{array}$ \\
\hline Amfoterisin B & $10 / 63(15.87)$ & $19 / 57(33.3)$ \\
\hline Caspofungin & $0 / 90(0)$ & $4 / 71(5.6)$ \\
\hline Flukonazol & $51 / 64(79.69)$ & $31 / 57(54.3)$ \\
\hline Vorikonazol & $84 / 88(95.45)$ & $27 / 66(40.9)$ \\
\hline${ }^{*}$ Dirençli izolat sayısı / Çalışılan izolat sayısı \\
\hline
\end{tabular}

TARTIŞMA

Kan dolaşımı enfeksiyonlarında tedavi planlaması yapılırken klinik bulguların yanı sıra laboratuvar bulgularının da değerlendirilmesi büyük önem taşımaktadır. Ülkemizde yapılan çalışmalarda kan kültürü örneklerinin daha çok dahili servislerden geldiği görülmektedir., ${ }^{5,8}$ Bolukçu ve ark. yaptığ lerinin dahili servislerden geldiği belirlenmiştir. ${ }^{8}$ Er ve ark. örneklerin en çok dahili servislerden geldiğini bildirmişlerdir. ${ }^{5}$ Bizim çalışmamızda da en çok dahili servislerden \%61.68 oranıyla örnek geldiği görülmüştür. (Tablo 2)

Üreyen mikroorganizmaların izolasyon sıklığına bakıldığında Gram pozitif bakterilerin daha fazla ürediği görülmektedir. ${ }^{5,7,910}$ Ülkemizde yapılan çalışmalarda Er ve ark. $\% 64.2$ Gram pozitif, \%32 Gram negatif; Ergül ve ark. \%60.2 Gram pozitif, $\% 33$ Gram negatif ; Özkaya ve ark. \%68.2 Gram pozitif, \%26.1 Gram negatif; Gündoğdu ve ark. \%68 Gram negatif, \%32 Gram pozitif olarak bulmuştur. 5,7,10,11 Yurt dışında yapılan çalışmalardaysa Opota ve ark. \%62 Gram negatif, \%35.4 Gram pozitif; Canzoneri ve ark. \%54 Gram pozitif, \%37 Gram negatif olarak bulmuşlardır., ${ }^{9}$ Bizim çalışmamızda da yukarıdaki bilgilere paralel olarak \%75.88 sıklıkta Gram pozitif bakterilerin, \%16.77 sıklıkta Gram negatif bakterilerin, \%2.44 sıklıkta Candida albicans türü mayaların ürediği görülmüştür.

Tür düzeyinde en sık izole edilen mikroorganizmalara bakıldığında ülkemizde ilk sırayı KNS türlerinin aldığı görülmektedir. ${ }^{710,13}$ KNS oranlarını Ergül ve ark. \%45, Özkaya ve ark \%58, Şafak ve ark. \%35 olarak ilk sırada bulmuşlardır. ${ }^{710,13}$ Yurtdışında yapılan çalışmalarda ise Keihanian ve ark. \%29 Pseudomonas aeruginosa, \%22 oranında KNS bulmuşlardır. ${ }^{6}$ Gandra ve ark. ise \% 23 KNS, \%17 Salmonella spp. bulunmuştur. ${ }^{14}$ Bizim çalışmamızda da oranlar daha yüksek olmakla birlikte \%60.36 KNS, \%6.74 Enterococcus spp, \%6.1 Escherichia coli bulunmuştur.(Tablo 1)

Dünya Sağlık Örgütü, antibiyotik direnci sürveyans ile ilgili küresel raporunda antibiyotik direncinin ciddi bir halk sağllğı sorunu haline geldiğini bildirmiştir. ${ }^{15} \mathrm{Gram}$ pozitif bakterilerin ilaç dirençlerine bakıldığında ülkemizdeki metisilin dirençli KNS oranı \%54-89 arasında değişmektedir. ${ }^{1,7,10,14,16}$ Metisilin dirençli Staphylococcus aureus (MRSA) oranı ise \%34-66 olarak bulunmuştur. 17,710,16,17 Yaptığımız çalışmada bu oranlar MRSA için \%55, MR KNS için \%84’tür.

Enterococcus spp. bakıldığında ise ülkemizde Ödemiş ve ark. vankomisin direncini \%17, Ergül ve ark. ise \%3.6 bulmuşlardır. ${ }^{10,18}$ Yurtdışında yapılan bir çalışmada ise bu oran \%23 olarak bulunmuştur. ${ }^{4}$ Hastanemiz bulgularına bakıldığında ise bu oranın \%9.79 olduğunu görmekteyiz. Gram pozitif bakterilerin antibiyotik direnç oranları Tablo 4’te verilmiştir.

Gram negatif bakterilerin ilaç dirençleri yapılan çalışmalara bakıldığında Escherichia coli için karbapenem direncini Tabah ve ark. \%1, Özer Balın ve ark. \%20 olarak bulunmuştur. ${ }^{419}$ Yine yapılan çalışmalarda Enterobacter ailesi içerisinde yer alan bakteriler için en etkili antibiyotiklerin aminoglikozidler ve karbapenemler olduğu belirlenmiştir. ${ }^{13,20}$ Bizim çalışmamızda da yukarıdaki bilgilere uyumlu olarak en etkili antibiyotiklerin aminoglikozidler, karbapenemler ve tigesiklin olduğu belirlenmiştir.(Tablo 5)

Nonfermentatif bakterilerde yapılan çalışmalara bakıldığında Er ve ark. en etkili antibiyotiğin aminoglikozidler olduğunu bulmuşlardır. ${ }^{5}$ Şirin ve ark. Acinetobacter için en etkili antibiyotiğin kolitsin olduğunu ve Acinetoba- 
cter karbapenem direncinin \%95'in üstünde olduğunu bulmuşlardır. ${ }^{21}$ Ergül ve ark. Acinetobacter karbapenem direncini \%100 olarak bulmuşlardır. ${ }^{10}$ Yapılan diğer çalışmalarda Acinetobacter için kolistinin en etkili ilaç olduğu belirlenmiştir. ${ }^{13,19,20,22}$ Pseudomonas aeruginosa için Barış ve ark. amikasin ve siprofloksasini, Şafak ve arkadaşları karbapenemleri etkili bulmuştur. ${ }^{13,20}$ Yurtdışında yapılan bir çalışmada ise Acinetobacter için karbapenem direnci \%69, Pseudomonas için karbapenem direnci \%37 olarak belirlenmiştir. ${ }^{4}$ Yaptığımız çalışmada Acinetobacterlerin \%100 oranında karbapenem dirençli olduğu belirlenmiştir. Pseudomonasların karbapenem direncinin meropenem için \%30.9, imipenem için \%37.5 olduğu belirlenmiştir. Her iki bakterinin duyarlı olduğu antibiyotiğin kolistin olduğu saptanmıştır. Burkholderia cepacia türlerinde Trimetoprim/Sulfameteksazol direnci saptanmamıştır.(Tablo 3)

Candidalara bakıldığında Aydın ve ark. Candida spp. oranını \%21, Gandra ve arkadaşları \%6.4 olarak bulmuşlardır. ${ }^{14,22}$ Bizim çalışmamızda Canida albicans \%2.44, Non-albicans Candida spp. \%2.39 olarak belirlenmiştir. En etkili ilaç kaspofungin, ikinci sırada ise amfoterisin B bulunmuştur. (Tablo 6)

Bakterilerin direnç oranlarının bu denli yüksek olması enfeksiyon kontrol önlemlerinin artırılıp, hastane çalışanlarının daha dikkatli olmasını gerektirmektedir. Hastalar için en uygun olan antibiyotik seçilip mümkün olan en kısa sürede tedaviye başlanmalıdır. 
Sakarya Tip Dergisi 2019;9(3):485-491

KÜÇÜK ve Ark. Kan Kültürü Mikroorganizmaları ve Antibiyotik Duyarllıkları

\section{Kaynaklar}

1. Bastuğ A, Akıncı E, Aypak A, Kanyllmaz D, Aslaner H, But A, et al. The Evaluation of Healthcare Associated Bloodstream Infections at a Tertiary Care Hospital Between 2011 and 2015: Epidemiology and Mortality Risk Factors. Kafkas Journal of Medical Sciences 2017;7(1):1-6.

2. Goto M, Al-Hasan MN. Overall burden of bloodstream infection and nosocomial bloodstream infection in North America and Europe. Clinical microbiology and infection : the official publication of the European Society of Clinical Microbiology and Infectious Diseases 2013;19(6):501-9.

3. Rodríguez-Baño J, López-Prieto MD, Portillo MM, Retamar P, Natera C, Nuño E, et al. Epidemiology and clinical features of community-acquired, healthcare-associated and nosocomial bloodstream infections in tertiary-care and community hospitals. Clinical Microbiology and Infection 2010;16(9):1408-13.

4. Tabah A, Koulenti D, Laupland K, Misset B, Valles J, Bruzzi de Carvalho F, et al. Characteristics and determinants of outcome of hospital-acquired bloodstream infections in intensive care units: the EUROBACT International Cohort Study. Intensive Care Med 2012;38(12):1930-45.

5. Er H, AȘIk G, YoldaS Ö, DemIR C, KeȘLİ R. Kan Kültürlerinde İzole Edilerek Tanımlanan Mikroorganizmaların ve Antibiyotik Direnç Oranlarının Belirlenmesi. Türk Mikrobiyoloji Cemiyeti Dergisi 45(1):48-54, 2015.

6. Keihanian F, Saeidinia A, Abbasi K, Keihanian F. Epidemiology of antibiotic resistance of blood culture in educational hospitals in Rasht, North of Iran. Infection and drug resistance 2018;11:1723-8.

7. Özkaya E, Tümer S, Kirisci Ö, Calıskan A, Erdoğmus P. Evaluation of microorganisms isolated from blood cultures and antibiotic sensitivity obtained at Kahramanmaraș Necip Fazll City Hospital in the last two years. Turkish Bulletin of Hygiene and Experimental Biology 2015;72(2):115-22.

8. Bolukçu S, Başaran S, Çağatay A, Özsüt H, Eraksoy H. Klinik Mikrobiyoloji Laboratuvarına Gönderilen Kan Kültürlerinin Prospektif Olarak Değerlendirilmesi. Klimik Dergisi 2018;31(2):120-4.

9. Canzoneri CN, Akhavan BJ, Tosur Z, Andrade PEA, Aisenberg GM. Follow-up blood cultures in Gram-negative bacteremia: Are they needed? Clinical Infectious Diseases 2017;65(11):1776-9.

10. Ergul AB, Isik H, Altintop YA, Torun YA. A retrospective evaluation of blood cultures in a pediatric intensive care unit: a three year evaluation. Turk pediatri arsivi 2017;52(3):15461.

11. Gundogdu A, Kilic H, Ulu-Kilic A, Aydin G, Alp E. Epidemiological Features of Nosocomial Bloodstream Infections in Pediatric Patients. Klimik Dergisi/Klimik Journal 2016;29(1):2935 .
12. Opota O, Croxatto A, Prod'hom G, Greub G. Blood culture-based diagnosis of bacteraemia: state of the art. Clinical microbiology and infection : the official publication of the European Society of Clinical Microbiology and Infectious Diseases 2015;21(4):313-22.

13. Safak B, Kilinc O. Microorganisms Isolated From Blood Cultures During 2010-2015 and Their Antimicrobial Susceptibilities. Klimik Dergisi/Klimik Journal 2016;29(2):61-5.

14. Gandra S, Mojica N, Klein EY, Ashok A, Nerurkar V, Kumari M, et al. Trends in antibiotic resistance among major bacterial pathogens isolated from blood cultures tested at a large private laboratory network in India, 2008-2014. International journal of infectious diseases :IJID : official publication of the International Society for Infectious Diseases 2016;50:75-82.

15. Organization WH. Antimicrobial resistance global report on surveillance: 2014 sum mary. World Health Organization, 2014. https://apps.who.int/iris/bitstream/handle/10665/112647/WHO_HSE_PED_AIP_2014.2_eng.pdf;jsessionid=20EDD94C5021CE41452D59E21677086D? sequence $=1$

16. Küçükateş E, Gültekin N. Antimicrobial Susceptibility and Microorganisms Isolated from Blood Cultures of Hospitalized Patients in Intensive Care Units. Haseki Tip Bülteni 2016;54(2):97-102.

17. Nazik S, Cingöz E, Șahin AR, Güler S. Kan kültürlerinden izole edilen Staphylococcus aureus suşlarında metisilin direncinin yıllara göre değișimi. Kocaeli Tip Dergisi 2018;7(1):32

18. Ödemiş İ, Köse Ş, Ersan G, Çelik D, Akbulut İ. Evaluation of antibiotic susceptibilities of enterococcus strains isolated from clinical samples of hospitalized patients. Turkish Bulletin of Hygiene and Experimental Biology 2018;75(4):345-52.

19. Ozer Balin S, Aktas Senol A. Evaluation of Hospital Infections in Intensive Care Unit. Klimik Dergisi/Klimik Journal 2017;30(3):108-13.

20. Barıș A, Bulut ME, Öncül A, Bayraktar B. Distribution of Clinical Isolates at Species Level and Their Antibiotic Susceptibilities in Intensive Care Units Patients. Türk Yoğun Baktm Derneği Dergisi 2017;15(1):21-7.

21. Sirin MC, Ağus N, Yllmaz N, Derici YK, Hancı SY, Bayram A, et al. The change of antibiotic resistance profiles over the years in Pseudomonas aeruginosa and Acinetobacter baumanni strains isolated from intensive care units. Journal of Clinical and Experimental Investigations 2015;6(3).

22. Aydin M, Kasikcioglu C, Nargiz Kosucu S, Timurkaynak F, Arslan H. Bloodstream Infections: Etiologic Agents and Their Antibiotic Resistance Rates. Klimik Dergisi/Klimik Journal 2016;29(2):83-6. 